\title{
Testing the Truth of Phrenology: Knowledge Experiments in Antebellum American Cultures of Science and Health
}

\author{
CARLA BITTEL * \\ Loyola Marymount University, Department of History, One LMU Dr., Suite 3500, \\ Los Angeles, CA 90045, USA
}

\begin{abstract}
In the first half of the nineteenth century, many Americans visited phrenological practitioners. Some clients were true believers, who consulted phrenology to choose an occupation, select a marriage partner and raise children. But, as this article demonstrates, many others consumed phrenology as an 'experiment', testing its validity as they engaged its practice. Consumers of 'practical phrenology' subjected themselves to examinations often to test the phrenologist and his practice against their own knowledge of themselves. They also tested whether phrenology was true, according to their own beliefs about race and gender. While historians have examined phrenology as a theory of the mind, we know less about its 'users' and how gender, race and class structured their engagement. Based on extensive archival research with letters and diaries, memoirs and marginalia, as well as phrenological readings, this study reveals how a continuum of belief existed around phrenology, from total advocacy to absolute denunciation, with lots of room for acceptance and rejection in between. Phrenologists' notebooks and tools of salesmanship also show how an experimental environment emerged where phrenologists themselves embraced a culture of testing. In an era of what Katherine Pandora has described as 'epistemological contests', audiences confronted new museums, performances and theatres of natural knowledge and judged their validity. This was also true for phrenology, which benefited from a culture of contested authority. As this article reveals, curiosity, experimentation and even scepticism among users actually helped keep phrenology alive for decades.
\end{abstract}

Keywords: Phrenology, Experiments, Users, Testing, Gender, Race

* Email address for correspondence: Carla.Bittel@1mu.edu

I would like to thank the editors at Medical History and anonymous reviewers at the journal for their helpful feedback. I am grateful to participants in the workshop 'Phrenology, Anthropometry, and Craniology: Historical and Global Perspectives' and to its organisers, Stephen Casper, Julia Rodriguez and Courtney Thompson; thanks also to Clarkson University and the David A. Walsh Arts and Sciences Seminar Fund. My sincere appreciation goes to those who read and commented on this piece: Emily K. Abel, Charlotte Borst, Janet Farrell Brodie, Lisa Forman Cody, Sharla Fett, Kimberly Hamlin, Daniel Martinico and Alice Wexler. Fenneke Sysling also shared insights and an important source. Thanks also to Nishan Silva and Nicholas Forshaw for their assistance, and to Russell Johnson and the UCLA History and Special Collections for the Sciences. Research for this article was supported by the National Endowment for the Humanities Summer Stipends and Loyola Marymount University. 
In December of 1838, a Delaware woman, Phoebe George Bradford, reacted to her phrenological reading in her diary. She was 'much amused'. Bradford wrote, 'Fowler told me I had [the organ of] order unusually developed. . . that I had a place for everything and everything in its place.' Her response: 'Quite a mistake. . ' By 'Fowler' she meant Orson Squire Fowler, who with his brother Lorenzo Niles Fowler and their associate Samuel Wells would build the famous Fowler and Wells phrenological empire. Bradford noted that he remarked on her strong energy and perseverance. Her self-esteem was fully developed, too, which was unusual, for 'not one woman in fifty has this organ even moderate', he explained. According to Fowler, Bradford supposedly jumped quickly from one topic to another; on this, she wrote, 'he hit the truth exactly'. Finally, Fowler said that her husband was 'a meek, quiet man who was silent when [she] was finding fault'. Bradford noted, 'not always the case certainly'. While Fowler said she was a kind, affectionate parent, she also 'love[d] to command and not brook submission'. Bradford found fault with some of his assessment, especially the suggestion that she was domineering. And yet she still went to hear him lecture the next day at the Hall of Natural Sciences. ${ }^{1}$

Phoebe George Bradford's mixed response to Fowler was not unusual. In the first half of the nineteenth century, many Americans recorded their phrenological encounters and commonly noted their agreements and disagreements with the findings. These letters, diaries and personal notes reveal a dynamic between clients and practitioners largely unexplored by historians. ${ }^{2}$ Such sources also illustrate the circulation of ideas among ordinary people, mostly from the middle classes, who engaged with American cultures of health and natural knowledge. ${ }^{3}$ Certainly, many people were true believers who considered it a 'science' and consulted phrenology to decide on an occupation, select a marriage partner and raise children. But, as this article demonstrates, many others consumed phrenology as an experiment, testing its validity as they engaged its practice. Many consumers of 'practical phrenology', in particular, subjected themselves to examinations to test the phrenologist and his practices against their own knowledge of themselves. Therefore, a continuum of belief existed around phrenology, from total advocacy to absolute denunciation, with lots of room for acceptance and rejection in between.

Historians have examined the history of phrenology as a telling chapter in the politics of knowledge and cultural authority. ${ }^{4}$ In the United States, they have located it in the context

\footnotetext{
${ }^{1}$ Phoebe George Bradford, Diaries of Phoebe George Bradford, 1832-9, W. Emerson Wilson (ed.) (Wilmington, DE: Historical Society of Delaware, 1976), 73.

${ }^{2}$ Although the practitioner-client dynamic needs further examination, important analysis can be found in Michael M. Sokal, 'Practical phrenology as psychological counseling in the 19th-century United States', in C. D. Green et al. (eds), The Transformation of Psychology: Influences of 19th-Century Philosophy, Technology, and Natural Science (Washington, DC: American Psychological Association, 2001), 21-44.

3 There is an expanding literature on knowledge transfer, circulation and diffusion, especially in the global context. On the transit and transfer of phrenological knowledge specifically, see James Poskett, 'Phrenology, Correspondence, and the Global Politics of Reform, 1815-48', The Historical Journal, 60, 1, (2016), 409-42; Fenneke Sysling, 'Science and Self-Assessment: Phrenological Charts 1840-1940', British Journal for the History of Science, 51, 2 (2018), 261-80; John van Wyhe, 'The diffusion of phrenology through public lecturing', in Aileen Fyfe and Bernard Lightman (eds), Science in the Marketplace: Nineteenth-Century Sites and Experiences (Chicago: University of Chicago Press, 2007), 60-96.

${ }^{4}$ Roger Cooter, The Cultural Meaning of Popular Science: Phrenology and the Organization of Consent in Nineteenth-Century Britain (Cambridge: Cambridge University Press, 1984); Sherrie Lynne Lyons, Species, Serpents, Spirits, and Skulls: Science at the Margins in the Victorian Age (Albany: SUNY Press, 2009); Steven Shapin, 'The Politics of Observation: Cerebral Anatomy and Social Interests in the Edinburgh Phrenology Disputes', The Sociological Review, 27, 1 (1979), 139-78; Steven Shapin, 'Phrenological Knowledge and the Social Structure of Early Nineteenth-Century Edinburgh', Annals of Science, 32, 3 (1975), 219-43;
} 
of social reform, the Age of Jackson and alternative-health movements. ${ }^{5}$ Scholars have deepened our understanding of phrenology as a racial science and its role in the politics of slavery. ${ }^{6}$ While we know about phrenology as a theory of the mind, we know less about its practices, such as the tacit and visual modes of analysis, the client-practitioner encounter and the technologies for recording and disseminating knowledge. We know even less about its 'users', particularly the many loyal and doubtful clients and consumers. ${ }^{7}$ In other words, we know phrenology's premises and prescriptions, articulated in voluminous print material, but less about how its principles played out in daily life. Historian Michael Sokal has importantly argued that historians need to think beyond the 'programmatic writings' of Franz Joseph Gall and phrenology's early thinkers, and to 'examine its practice and determine just how its practitioners created their "knowledge". Sokal's article analogises practical phrenology and 'psychological counseling' and suggests that phrenological analyses were less a product of skull reading than the result of a skilful interpreter, who read a subject's appearance and gestures and pleased clients with vague, positive reinforcement. ${ }^{8}$ As we further unpack phrenological techniques, we can better understand how expectations for race and gender impacted the 'reading' of bodies, as practitioners interpreted heads and faces according to particular visual markers. We can also see the local impact of global phrenological endeavours, as practitioners applied colonial and racialised theories of human difference to individual phrenological assessments.

This article also seeks to understand practices, but it goes beyond the techniques of the analyst by revealing the practices of both the phrenologist and the phrenologised. Situated

John van Wyhe, Phrenology and the Origins of Victorian Scientific Naturalism (Aldershot: Ashgate Publishing, Ltd., 2004).

${ }^{5}$ On phrenology in the United States, see Carla Bittel, 'Woman, Know Thyself: Producing and Using Phrenological Knowledge in 19th-Century America', Centaurus, 55, 2 (2013), 104-30; Charles Colbert, A Measure of Perfection: Phrenology and the Fine Arts in America (Chapel Hill: University of North Carolina Press, 1997); John Dunn Davies, Phrenology: Fad and Science: A 19th-Century American Crusade (New Haven: Yale University Press, 1955); Allan S. Horlick, 'Phrenology and the Social Education of Young Men', History of Education Quarterly, 11, 1 (1971), 23-38; Cynthia Eagle Russett, Sexual Science: The Victorian Construction of Womanhood (Cambridge, MA: Harvard University Press, 1989); Sokal, op. cit. (note 2); Madeleine B. Stern, Heads \& Headlines: The Phrenological Fowlers (Norman, OK: University of Oklahoma Press, 1971); Daniel Patrick Thurs, Science Talk: Changing Notions of Science in American Popular Culture (New Brunswick, NJ: Rutgers University Press, 2007; Christopher G. White, 'Minds Intensely Unsettled: Phrenology, Experience, and the American Pursuit of Spiritual Assurance, 1830-80', Religion and American Culture: A Journal of Interpretation, 16, 2 (2006), 227-61.

${ }^{6}$ Susan Branson, 'Phrenology and the Science of Race in Antebellum America', Early American Studies: An Interdisciplinary Journal, 15, 1 (2017), 164-93; Ann Fabian, The Skull Collectors: Race, Science, and America's Unburied Dead (Chicago: University of Chicago Press, 2010); Stephen Jay Gould, 'American polygeny and craniometry before Darwin: Blacks and Indians as separate, inferior species', in Sandra Harding (ed.), The 'Racial' Economy of Science: Toward a Democratic Future (Bloomington: Indiana University Press, 1993), 84115; John S. Haller, 'Concepts of Race Inferiority in Nineteenth-Century Anthropology', Journal of the History of Medicine and Allied Sciences, 25, 1 (1970), 40-51; Cynthia S. Hamilton, "“Am I Not a Man and a Brother?" Phrenology and Anti-Slavery', Slavery \& Abolition, 29, 2 (2008), 173-87; James Poskett, 'National Types: The Transatlantic Publication and Reception of Crania Americana (1839)', History of Science, 53, 3 (2015), $264-95$.

7 'Users' here refers to individuals and social groups that put phrenology to use in different ways. I am applying the literature from the history and sociology of technology to better understand how actors shaped and negotiated knowledge and practices. See Ronald Kline and Trevor Pinch, 'Users as Agents of Technological Change: The Social Construction of the Automobile in the Rural United States', Technology and Culture, 37, 4 (1996), 76395; Nelly Oudshoorn and Trevor Pinch (eds), How Users Matter: The Co-Construction of Users and Technology (Cambridge, MA: MIT Press, 2003); Trevor J. Pinch and Wiebe E. Bijker, 'The Social Construction of Facts and Artefacts: Or How the Sociology of Science and the Sociology of Technology Might Benefit Each Other', Social Studies of Science, 14, 3 (1984), 399-441.

${ }^{8}$ Sokal, op. cit. (note 2), 43. 
within the cultures of healing and natural knowledge before the American Civil War (1861-5), it analyses practical phrenology as a dynamic encounter between practitioners and consumers, in which consumers took an active role and phrenology's authority could be challenged. ${ }^{9}$ At a time of eclecticism in American medicine, when 'regular', orthodox medicine competed with, for example, homeopathy, hydropathy, botanic medicine and household remedies, those with some means could choose from a host of healing options to treat body and mind. But these choices had their limitations, for phrenology mirrored larger contestations around power, knowledge and authority in the realm of medicine. ${ }^{10}$ Combining therapeutic, epistemic and commercial elements, phrenology represented a complex set of negotiations between users. In many ways, phrenological concepts of character and natural order reflected and upheld bourgeois norms and perpetuated the industrial order in the United States and Britain. ${ }^{11}$ Some historians have argued that although phrenology could be anti-establishment and popular among the working class, it still conditioned followers through simplified constructs of science and natural law. ${ }^{12}$ But in the American context, an interactive epistemic interplay occurred between users, one that mirrored the fluid and contested nature of medical authority itself. As we will see, phrenological knowledge was co-constituted by practitioners and subjects whose knowledge and practices were more entangled and similar than one might imagine.

Phrenology thrived within what has been called the 'republican ethos' of antebellum America, which maintained that knowledge, in theory, should be attainable and accessible. ${ }^{13}$ As Katherine Pandora has described, it was an era of 'epistemological contests', when audiences confronted new museums, performances and theatres of natural knowledge that 'authorized the public to judge for themselves rather than defer to the authority of experts'. ${ }^{14}$ Clients and consumers of phrenology enrolled in these contests via encounters with practitioners and lecturers that blurred the lines of expertise. In these exchanges, consumers measured the accuracy of phrenological measurements and often borrowed the methods and discourses of natural inquiry, and phrenology itself, to carry

\footnotetext{
${ }^{9}$ On modes of healing in this period, see Elaine G. Breslaw, Lotions, Potions, Pills, and Magic: Health Care in Early America (New York: New York University Press, 2012); Janet Farrell Brodie, Contraception and Abortion in Nineteenth-Century America (Ithaca, NY: Cornell University Press, 1994); Susan E. Cayleff, Wash and Be Healed: The Water-Cure Movement and Women's Health (Philadelphia: Temple University Press, 1987); Regina Markell Morantz-Sanchez, Sympathy \& Science: Women Physicians in American Medicine (New York: Oxford University Press, 1985); John Harley Warner, The Therapeutic Perspective: Medical Practice, Knowledge, and Identity in America, 1820-85 (Cambridge, MA: Harvard University Press, 1986).

${ }^{10}$ On patients and questions of authority in medicine, see L. Stephen Jacyna and Stephen T. Casper (eds), The Neurological Patient in History (Rochester, NY: University of Rochester Press, 2012); Dorothy Porter and Roy Porter, Patient's Progress: Doctors and Doctoring in Eighteenth-Century England (Stanford, CA: Stanford University Press, 1989); Catherine L. Thompson, Patient Expectations: How Economics, Religion, and Malpractice Shaped Therapeutics in Early America (Amherst, MA: University of Massachusetts Press, 2015); Warner, op. cit. (note 9).

${ }^{11}$ Elizabeth Green Musselman, Nervous Conditions: Science and the Body Politic in Early Industrial Britain (Albany, NY: State University of New York Press, 2006); Christopher Lawrence, 'The nervous system and society in the Scottish Enlightenment', in Barry Barnes and Steven Shapin (eds), Natural Order: Historical Studies of Scientific Culture (Beverly Hills: Sage Publications, 1979), 19-40; Roger Smith, Inhibition: History and Meaning in the Sciences of Mind and Brain (Berkeley, CA: University of California Press, 1992).

${ }^{12}$ For example, see Cooter, op. cit. (note 4), chapter 6.

13 Katherine Pandora, 'Popular Science in National and Transnational Perspective: Suggestions from the American Context', Isis, 100, 2 (2009), 346-58: 350. On colonial origins of resistance to knowledge hierarchies, see Susan Scott Parrish, American Curiosity: Cultures of Natural History in the Colonial British Atlantic World (Chapel Hill, NC: University of North Carolina Press, 2006).

${ }^{14}$ Ibid. See also James W. Cook, The Arts of Deception: Playing with Fraud in the Age of Barnum (Cambridge, MA: Harvard University Press, 2001).
} 
out their assessments. And by contesting and claiming knowledge, users like Phoebe George Bradford could hope to gain some sense of epistemic authority over themselves and others. ${ }^{15}$

Certainly, multiple factors made phrenology appealing to different audiences. As I argue elsewhere, questions of sex difference, as well as phrenology's applicability to marriage, child-rearing and the family, attracted many dedicated women users. ${ }^{16}$ Notions of biological difference between races and peoples, along with the politics of slavery, also propelled phrenological interest in the United States. ${ }^{17}$ But gender and race were also embedded in knowledge contests and played a role in phrenology's dissemination. Clients held preconceptions about gender and racial features, and they evaluated phrenology's validity according to how well it corroborated their perceptions of self and others. Many readers intended to reaffirm, if not try to elevate, their place in the so-called natural order by appraising their own 'Caucasian' features and identifying non-European traits. Many women readers found facial and cranial juxtapositions adaptable for affirming their femininity. For many users, race and gender became another measurement of phrenology's usefulness; they did not just digest concepts of human difference but tested and perpetuated them as they tested phrenology.

While some observers claim that phrenology died out in the United States because it was discredited by the rise of professional science and medicine, or due to shifting models of American reform, ${ }^{18}$ this article maintains that curiosity, experimentation and even scepticism actually kept phrenology, especially practical phrenology, alive for decades. ${ }^{19}$ Doubtful audiences were still attentive audiences, who paid for phrenological readings, filled lecture halls and may have felt a head or two themselves, as they engaged with the knowledge in question. Embedded in the medical and consumer cultures of the midnineteenth century, many Americans chose phrenology as an epistemological product, one they were ready to utilise but also willing to scrutinise.

\section{Phrenological Encounters as Knowledge Contests}

In the second quarter of the nineteenth century, lower Manhattan was an urban centre of natural wonders. New Yorkers and tourists alike could stroll Broadway and adjacent

\footnotetext{
15 John van Wyhe argues that phrenology involved 'personal competition for status and authority' between individuals (as opposed to social groups) but focuses on phrenology's famous advocates and theorists, rather than ordinary users. See Van Wyhe, op. cit. (note 4), 12; John van Wyhe, 'Was Phrenology a Reform Science? Towards a New Generalization for Phrenology’, History of Science, 42, 3 (2004), 313-31.

${ }^{16}$ Bittel, op. cit. (note 5); Russett, op. cit. (note 5).

17 On race and phrenology, see Andrew Bank, "Of "Native Skulls" and "Noble Caucasians": Phrenology in Colonial South Africa', Journal of Southern African Studies, 22, 3 (1996), 387-403; Neil Davie, 'Mapping the racial other: phrenology, race and colonial discourse in Britain, c.1810-50', published in French as 'Garder la race en tête: phrénologie, race et discours colonial en Grande-Bretagne, c.1810-50', in Michel Prum (ed.), Racialisations Dans l'aire Anglophone (Paris: L'Harmattan, 2012), 17-49; Fabian, op. cit. (note 6); Gould, op. cit. (note 6); Haller, op. cit. (note 6); Poskett, op. cit. (note 6); Poskett, op. cit. (note 3); William Ragan Stanton, The Leopard's Spots: Scientific Attitudes toward Race in America, 1815-59 (Chicago: University of Chicago Press, 1960); Nancy Leys Stepan, 'Race and Gender: the Role of Analogy in Science', Isis, 77, 2 (1986), 261-77.

18 On shifting modes of reform, see Davies, op. cit. (note 5), 172-4; Sokal, op. cit. (note 2), 42. Sokal argues that the shift from antebellum reform to late nineteenth-century reform, or the transition from individual improvement to broader social change via the state, explains the decline of phrenology.

${ }^{19}$ Cook, op. cit. (note 14), 6, 16. Cook describes how P.T. Barnum invited audiences to judge ambiguous displays for themselves, and argues that this aided his success. Phrenologists shared this cultural script of 'decide for yourself' and also thrived on audience uncertainty.
} 
streets and find a thriving commercial culture of natural curiosities. Many viewers flocked to Phineas T. Barnum's American Museum to see an array of unusual displays, from the Feejee Mermaid, to talking automata, to live subjects, such as trained chickens and 'bearded ladies'. Driven by curiosity and questions of validity, many patrons wanted to see and judge Barnum's hoaxes and specimens for themselves. ${ }^{20}$ This invitation to judge the validity of a natural object applied to phrenological assessments as well.

But O.S. Fowler was not P.T. Barnum. While the Fowler and Wells Phrenological Cabinet was not far from Barnum's American Museum, and advertised in Barnum's guide books, the phrenologists did not trade in creative hoaxes or the display of ambiguous bodies. ${ }^{21}$ Instead, they purported to present firm truths and realistic specimens related to the human mind. While critics accused them of fraud and deception, most phrenologists swore obedience to principles of the science. ${ }^{22}$ They may have been crafty salesman and dynamic showmen, but in public and private, lectures and personal diaries, they often expressed firm convictions. Public uncertainty provoked strong reactions from phrenologists, who went to great lengths to prove their validity. Phrenology's epistemological contests had their own stages and performances, where reciprocal acts of assessment transpired between consumers and practitioners. Phrenologists analysed subjects, while subjects and audiences judged the skills and character of the phrenologist. Drawing great crowds and attention, phrenology flourished as it was put on trial. ${ }^{23}$

In the first half of the nineteenth century, phrenology was part of a larger series of epistemological contests over the truths of the natural world. Barnum was just the beginning. Multiple sources of authority and systems of knowledge coexisted and competed for attention. Scientific knowledge both blended with and challenged religious, agricultural, medical and domestic knowledge. This was made possible by the accessibility of the sciences and their lack of firm boundaries. As Daniel Patrick Thurs has shown, phrenology and other sciences often garnered interest not because they were erudite but because the science was useful and accessible. Geology and botany, spiritualism and shorthand, all claimed to be sciences on multiple grounds: as sites of natural inquiry, as sources of systematic study and observation, as useful sources of knowledge. ${ }^{24}$ Before the Civil War era, since 'science was something anyone could [do]', scientific authority was something many tried to claim. ${ }^{25}$ Natural knowledge was open to varying levels of training

${ }^{20}$ Cook, op. cit. (note 14); Neil Harris, Humbug: The Art of P.T. Barnum, (Chicago: University of Chicago Press, 1981); Katherine Pandora, 'The permissive precincts of Barnum's and Goodrich's museums of miscellaneity: lessons in knowing nature for new learners', in Carin Berkowitz and Bernard Lightman (eds), Science Museums in Transition: Cultures of Display in Nineteenth-Century Britain and America (Pittsburgh, PA: University of Pittsburgh Press, 2017), 36-64; Benjamin Reiss, The Showman and the Slave: Race, Death, and Memory in Barnum's America (Cambridge, MA: Harvard University Press, 2010).

${ }^{21}$ Barnum's American Museum was at the corner of Broadway and Ann Street, and the Phrenological Cabinet was at 129 and 131 Nassau Street. See an advertisement for the Phrenological Cabinet in Phineas T. Barnum, Barnum's American Museum Illustrated (New York: William Van Norden and Frank Leslie, 1850).

22 On fears of deception and the culture of authenticity in the nineteenth century, see Karen Halttunen, Confidence Men and Painted Women: A Study of Middle-Class Culture in America, 1830-70 (New Haven: Yale University Press, 1982).

${ }^{23}$ For analysis of phrenology on trial in criminal courts, see Courtney Elizabeth Thompson, 'Criminal Minds: Medicine, Law, and the Phrenological Impulse in America, 1830-90'(unpublished PhD thesis: Yale University, 2015).

${ }^{24}$ Elizabeth B. Keeney, The Botanizers: Amateur Scientists in Nineteenth-Century America (Chapel Hill, NC: University of North Carolina Press, 1992); R. Laurence Moore, 'Spiritualism and Science: Reflections on the First Decade of the Spirit Rappings', American Quarterly, 24, 4 (1972), 474-500.

25 Thurs, op. cit. (note 5), 48-9. 
and experience, from formal instruction to self-study, for, as Sally Gregory Kohlstedt has shown, science circulated in 'parlors, primers, and public schooling'. ${ }^{26}$ A variety of spaces - the home, the market, the stage, the museum - later deemed as 'outside' science and medicine, hosted scientific investigations. ${ }^{27}$ And in this context, without firm lines of expertise, where speculation and exploration thrived, stood the foundation for many knowledge contests of the period. ${ }^{28}$

In a similar mode to phrenology, animal magnetism captivated American audiences who sat in both doubt and amazement and submitted themselves to experiments with mesmerists. As Alison Winter argued, in Britain, debates about the value and truth of mesmerism became, ultimately, the focal point of larger 'contests over authority in science, medicine, and intellectual life'. ${ }^{29}$ She also described the 'mesmeric duels' that occurred between magnetisers and their reluctant subjects as both vied for control during their encounters. Phrenological 'duels' had their own specific character. They focused not on the altered state of the mind and manipulation of bodies (unless they were phreno-mesmerists) but on revealing and documenting the essence of character; phrenological contests were less about moving bodies and more about the authority gained and lost over those bodies.

Despite phrenology's accessibility, practitioners claimed a level of expertise, as they tried to render their services beneficial and of necessity. A practical phrenologist could receive training, learn techniques of measurement, advertise specialised skills and hand down recommendations to clients for health and mental acuity. And yet phrenology also encouraged consumers to analyse themselves and to apply that knowledge to the assessment of others. Practical phrenological guides, labelled 'the self-instructor', preached 'knowledge is power' and encouraged self-study. Consumers needed the expertise of a phrenologist and yet were told they too could become skilled practitioners. They were lured to the experienced hands of the phrenologist but then urged to 'know thyself' and be active participants, investigators and even analysts. Assigned such roles, many consumers did not simply defer to an authority but tested phrenology and claimed it for themselves.

\section{'My Own Knowledge of Self'}

As we first saw in Phoebe George Bradford's diary, consumers did not just accept their phrenological readings as absolute truth; they assessed them and determined their utility and validity. While some accepted phrenology wholeheartedly, others rejected it completely, and still others took what was useful and combined it with what they already knew. As we explore practitioner-client dynamics, and resulting phrenological analyses, we see a series of knowledge contests. Constant acts of mutual corroboration and contestation played out in the parlour and the examining room, as practitioners and their subjects met in judgment of one another.

\footnotetext{
${ }^{26}$ Sally Gregory Kohlstedt, 'Parlors, Primers, and Public Schooling: Education for Science in NineteenthCentury America', Isis, 81, 3 (1990), 424-45.

${ }^{27}$ Christine von Oertzen et al., 'Finding Science in Surprising Places: Gender and the Geography of Scientific Knowledge. Introduction to "Beyond the Academy: Histories of Gender and Knowledge", Centaurus, 55, 2 (2013), 73-80; Donald L. Opitz et al. (eds), Domesticity in the Making of Modern Science (Basingstoke: Palgrave Macmillan, 2016); Katherine Pandora and Karen A. Rader, 'Science in the Everyday World: Why Perspectives from the History of Science Matter', Isis, 99, 2 (2008), 350-64.

${ }^{28}$ On speculation and sites of 'miscellaneity', see Pandora, op. cit. (note 20).

${ }^{29}$ Alison Winter, Mesmerized: Powers of Mind in Victorian Britain (Chicago: University of Chicago Press, 1998), $1,4$.
} 
Subjects submitting themselves for analysis could expect to have an assessment of their character, based on the measuring of their skulls and sizing of their 'faculties'. As men removed their hats, and women let down their braids or took off their bonnets, they permitted tactile inspection and physical contact from a stranger, an unusually intimate encounter in the Victorian era. Phrenologists stood above and behind clients, out of their sight, and used callipers to take measurements and moved their hands about their heads. Clients sat and listened to descriptions of organ size, often numbered one to seven, with seven as the largest. A practitioner would then interpret the meaning of those measurements, explaining what they indicated about a client. With sentences constructed with 'you' as the subject, such as 'you are...' and 'you have...', the phrenologist described the significance of organ size and said 'you will...' and 'you should' as he made recommendations. Subjects received a marked chart of those measurements, sometimes bound in a phrenological text and other times large and free-standing; they might also receive longer, narrative, descriptive delineations.

For practitioners, the paper record of the examination was a powerful mode from which to express authority. ${ }^{30}$ Whether purchased from Fowler and Wells or printed specifically for a practitioner, the phrenological chart affirmed a value to the services provided. Charts captured character and imposed order on the individual through standardised boxes and columns, blank and awaiting the practitioner's measurements and markings. ${ }^{31}$ Sometimes bound within books, filled-in charts suggested a permanent quality. They also served to stabilise and naturalise race and gender. High or low measurements in certain categories were supposedly more or less common in those considered to be of 'Caucasian' origin, or in men than in women. Thus, in books filled with juxtaposed images of representative typologies - contrasting portraits of George Washington and Benjamin Franklin with Black Hawk and indigenous skulls, and the heads of the 'motherly' and the 'unmotherly' readers could turn to their own measurements for reassurance that they either were or were not like the illustrations. ${ }^{32}$ One's own measurements were not isolated results: they were comparable with and 'relational' to others. ${ }^{33}$ But while paper records and self-instructor books could be used as stabilising agents, they were far from stable, as we will see. Clients could consult and reference paper records for years to come, but they could also refute them by complaining to others in correspondence, or penning commentary next to the phrenologist's measurements and assessments.

Adults who willingly submitted themselves for analysis went 'head to head' with phrenologists. Phrenologists seemed to be in control of the interaction, as clients became

\footnotetext{
${ }^{30}$ My research is greatly influenced by histories of paper technologies, which include: Ann Blair, 'Humanist Methods in Natural Philosophy: The Commonplace Book', Journal of the History of Ideas, 53, 4 (1992), 541-51; Anke te Heesen, 'The notebook: a paper technology', in Bruno Latour and Peter Weibel (eds), Making Things Public: Atmospheres of Democracy (Cambridge, MA: MIT Press, 2005), 582-9; Volker Hess and J. Andrew Mendelsohn, 'Case and Series: Medical Knowledge and Paper Technology, 1600-1900', History of Science, 48, $3 / 4$ (2010), 287-314; Lauren Kassell, 'Casebooks in Early Modern England: Medicine, Astrology, and Written Records', Bulletin of the History of Medicine, 88, 4 (2014), 595-625; Seth Rockman, 'Introduction to the Forum: The Paper Technologies of Capitalism', Technology and Culture, 58, 2 (2017), 487-505. See also Carla Bittel, Elaine Leong and Christine von Oertzen (eds), Working with Paper: Gendered Practices in the History of Knowledge (Pittsburgh, PA: University of Pittsburgh Press, forthcoming).

31 On phrenological charts, see also Sysling, op. cit. (note 3).

32 O.S. Fowler and L.N. Fowler, New Illustrated Self-Instructor in Phrenology and Physiology: With over One Hundred Engravings; Together with the Chart and Character of [Blank Line] as Marked by [Blank Line] (New York: Fowler and Wells, 1859), 81; O.S. Fowler, Fowler's Practical Phrenology; Giving a Concise Elementary View of Phrenology, 1st edn (Philadelphia: O.S. Fowler, 1840).

${ }^{33}$ Natalia Molina, 'Understanding Race as a Relational Concept', Modern American History, 1, 1 (2018), 101-5.
} 
the vulnerable objects of investigation. They read the physical evidence and announced its meaning, as if the findings were indisputable. But the burden of proof - that the science was valid and useful - was on them, as they had to perform satisfactorily. In the antebellum commercial culture, phrenology was one knowledge product selected from many. As the phrenologist uttered his description, the user responded; slight movements, facial expressions, breathing and posture could signal approval or discomfort. ${ }^{34}$ These living specimens were acted upon, but they also reacted. As the client heard or read the results of her examination, she decided how the analysis either conformed to or challenged what she already believed about herself. Curiously, accurate and inaccurate statements by the phrenologist could foster more interest in the science.

In many cases, consumers tested their phrenological analyses against their own selfknowledge. For example, one young man with initials 'A.N.' wrote to his brother and sister, updating them on his recent activities and describing his effort to settle on an occupation. He worked as a potter and on a farm but was also committed to his studies and improving his lot. On his way from Canada to Vermont, he turned to a phrenologist for vocational guidance. ${ }^{35}$ He recalled, "[the phrenologist] said I should make a grand mechanik. He said further more that I had been studying in some form or other for considerable time also that I was a lover of money. . consequently I generally made a good trade.' A.N. then evaluated his evaluator: 'He hit right on most every thing but missed occasionally. ${ }^{36}$ Future physician James Lawrence Dusenbery, a student at the University of North Carolina in 1841, used his diary to record poetry, songs, literary references, his studies in astronomy, zoology and mineralogy, his church attendance and all around student high jinks. That October, he also reported studying mental philosophy, the mind as matter and the question of materialism. In that same entry, he wrote about the phrenology craze on campus: "nearly all the students [were] getting their bumps felt' by a phrenologist named Woodward. Dusenbery was not completely sold, explaining, 'I believe in the science to some [extent], but not to the degree that it has been carried.' He did receive a reading, which only reinforced his ambivalence: 'He has hit my character \& disposition in some things but in others, I think he has erred.' Dusenbery was not searching for new information but seemed to be testing whether Woodward's reading was consistent with what he already knew about himself. Despite his misgivings, the numerical and descriptive results of his analysis were meticulously copied in his diary (Figure 1). ${ }^{37}$ These two young men, A.N. and Dusenbery, of different classes and education, one vocational and the other academic, used phrenologists to assert knowledge of themselves in their youth.

Upon receiving an analysis, some users tried to align phrenological findings with preexisting perceptions of self. One young teacher, Augusta, wrote to her friend Phebe, a fellow Normal School 'sister', in January of 1850 about the sorrows and joys of the previous year and her hopes for the future. She believed that hope could be cultivated

\footnotetext{
${ }^{34}$ Sokal, op. cit. (note 2), 41. Michael Sokal argues that subjects' physical movements and responses during examinations guided the phrenological reading and that reactions directed the practitioner in one way or another. 35 On phrenology and vocational guidance, see Horlick, op. cit. (note 5).

36 A.N. to Brother and Sister, n.d., Ms. Coll. 504.075, History and Special Collections for the Sciences, UCLA Library Special Collections.

${ }^{37}$ Phrenological Report, James Lawrence Dusenbery Diary and Clipping (1841-2), 114-5, \#2561-z, Southern Historical Collection, the Louis Round Wilson Special Collections Library, The University of North Carolina at Chapel Hill. Dusenbery's analysis appears to be copied into his diary, but it is of a slightly different hand, and signed 'Woodward', suggesting he could have traced it from the original analysis, or that Woodward or his assistant wrote it into his notebook.
} 
through training the mind, but also that it could be innate, and she wrote, 'The organ of hope is pretty fully developed in my pate, according to a certain Phrenologist as well as to my own knowledge of self, and I cannot say I am sorry it is so.' ${ }^{38}$ Augusta's recognition of self-knowledge reflected middle-class sensibilities as well as notions of self-culture. But her claim is also a declaration of shared authority with the phrenologist. By contesting or agreeing with a phrenologist, one could establish authority over oneself and one's body. For women, this could mean claiming to know themselves better than others, which could grant crucial degrees of autonomy.

Tensions often emerged when expectations around class and social roles did not match phrenological findings. For example, a Mr and Mrs Beall of Massachusetts reportedly saw great fault in the analysis Lorenzo or Orson Fowler gave of a woman named Hannah, possibly their employee. They thought that Fowler 'had rather missed her character, [her] true one' by making her out to be 'quite intellectual'. ${ }^{39}$ Feminist Elizabeth Cady Stanton chose a domestic, Rose, because she had 'all the points of a good servant, phrenologically and physiologically. She had a large head, with great bumps of caution and order, her eyes were large and soft and far apart.' Stanton claimed she selected her 'scientifically', based on her cranial and facial features, believing she found a 'treasure'. Clearly, notions of scientific selection were also laden with assumptions about class, race, gender and labour. Though Stanton believed in phrenology, she and her husband were forced to rethink their hiring methods when Rose 'carelessly burned' their baby's foot against the stove and reportedly at times lacked sobriety. ${ }^{40}$ While some users clearly hoped phrenology would serve as a trusted measuring device to predict character, many found themselves disappointed when their formulas did not add up.

Some men of science, already invested and fluent in matters of mind and body, took a particular interest in judging the precision of phrenology for themselves. In November 1838, Dr Jared Potter Kirtland, physician, naturalist, professor at the Medical College of Ohio in Cincinnati and co-founder of Cleveland Medical College, tested the findings of phrenologist Robert H. Collyer. Collyer gave Kirtland a copy of his book Manual of Phrenology, or the Physiology of the Human Brain, which contained a fold-out chart with Kirtland's measurements penned in by Collyer. ${ }^{41}$ Kirtland then reviewed each organ, one by one, and evaluated the veracity of each measurement. In most cases, he believed Collyer was correct and noted variations of 'True' in the margins: 'Perfectly true', 'True exactly' and 'Fact'. ${ }^{42} \mathrm{He}$ often annotated the measurement with explanations or additional evidence. For example, Collyer said his Destructiveness was moderate; Kirtland wrote, 'Very true - hunt to obtain specimens in Nat science. Their suffering distress me beyond

\footnotetext{
38 Augusta to Phebe A. Holder, 18 January 1850, Ms. Coll. no. 504.049, History and Special Collections for the Sciences, UCLA Library Special Collections, emphasis added.

${ }^{39}$ Sark to Lizzie, 18 May 1841, Ms. Coll. 504.052, History and Special Collections for the Sciences, UCLA Library Special Collections, emphasis original.

${ }^{40}$ Elizabeth Cady Stanton, Eighty Years and More: Reminiscences, 1815-97 (Boston: Northeastern University Press, 1993), 138-9.

${ }^{41}$ Robert H. Collyer, Manual of Phrenology, or the Physiology of the Human Brain, Embracing a Full Description of the Phrenological Organs, Their Exact Locations, and the Peculiarities of Character Produced by Their Various Degrees of Development and Combination, 3rd edn (Cincinnati, OH: Alexander Flash, 1838). See the Kirtland copy at the Cleveland Health Sciences Library, Case Western University; another copy was consulted at the Department of Archives and Special Collections, William H. Hannon Library, Loyola Marymount University, BF870.C64 1838.

${ }^{42}$ Ibid., 100, 76, 82.
} 
measure. ${ }^{43}$ He agreed that he had full Conscientiousness, sized 18 , for he 'Never intended to do a wrong act. ${ }^{44}$ In a few instances, he quibbled with Collyer and wrote, 'True to some extent' ${ }^{45}$ He took issue with his Constructiveness being small: 'The least correct $-[\mathrm{I}]$ have some mechanical ingenuity. ${ }^{46}$ Kirtland systematically audited the degrees of truth in Collyer's measurements, as he literally tested phrenology. Though Collyer was known as one of the more colourful characters on the phrenological circuit, Kirtland's notes suggest he took Collyer seriously, or at least he gave him a fair trial, for he concurred that his analysis was mostly accurate.

Some users submitted themselves for multiple phrenological examinations, using repetition and comparison as methods for testing phrenologists. Joseph Wood experimented with phrenology over many years, employing D.P. Butler in 1860 and Nelson Sizer in 1862, with A.M. Dewey added in 1904. The fourth analyst was Wood himself. On a manuscript page titled 'My Phrenology, and how the Phrenologists differ on it, by J.W.', attached to his 1852 copy of the New Illustrated Self-Instructor, Wood transcribed, compiled and compared the results of the examinations (Figure 2). ${ }^{47} \mathrm{He}$ copied the measurements in columns, with the first one, for his own assessment, labelled 'As believed by W'. And when the measurements matched up, he used a red pen to underline the replication. Wood, then, shared authority with practitioners and even privileged his selfknowledge. Combining phrenological analysis, empirical data collection, and replication, Wood's chart blends the analyst and analysed and represents the ways ordinary people inserted themselves into cultures of science.

One anonymous user chose to publish his five phrenological examinations, so that the public could judge phrenology. In his 1851 pamphlet Phrenological Test or Five Charts of the Same Faculties by as Many Distinguished Professors, the unnamed author presented the descriptive results of his charts. ${ }^{48} \mathrm{He}$ invited his readers to 'test the truth or falsity of the science' so that 'any person by comparing the charts can judge of their agreement and disagreements' ${ }^{49}$ His introductory remarks questioned the validity of the entire enterprise, and his lengthy annotations took issue with particular findings. These were followed by narratives from the 'blind phrenologist' Frederick Bly, Orson S. Fowler and then a Mr Ryan, a Mrs Julia F. Casler and J.R. Buchanan (likely Joseph Rodes Buchanan). Although the pamphlet started sceptically, the author concluded that 'phrenology is a science of truth and usefulness'; despite their differences, 'those charts are pretty good likenesses of my life'. And while he hoped his 'little sketch may do much good' for settling 'enquiring' minds, the Phrenological Test's juxtaposition of multiple examinations did not put the question of phrenology to rest. ${ }^{50}$ Rather, its uncertainty more likely fuelled interest among readers, potentially driving more of them to test phrenology for themselves.

43 Ibid., 74.

${ }^{44}$ Ibid., 107.

45 Ibid., 94.

46 Ibid., 105.

${ }^{47}$ Joseph Wood, 'My Phrenology and How the Phrenologists Differ on It', tipped into O.S. Fowler and L.N. Fowler, New Illustrated Self-Instructor in Phrenology and Physiology (New York: Fowler and Wells, 1852), BF870.F69 1850, Department of Archives and Special Collections, William H. Hannon Library, Loyola Marymount University.

48 Phrenological Test or Five Charts of the Same Faculties by as Many Distinguished Professors (Cincinnati, $\mathrm{OH}$ : printed by A. Pugh, 1851). I am grateful to Fenneke Sysling for this reference.

49 Ibid., 2, title page.

${ }^{50}$ Ibid., 13, 12. 


\section{Seeing Others Scientifically}

As consumers assessed their own readings, they did so conscious of race and class and with knowledge that the self was relational to others. ${ }^{51}$ Thus, for some white users of the middling classes, phrenology often affirmed much of what they wanted to believe about biological differences. Often confirming social hierarchies, phrenology became an organising principle for measuring 'civilisation'. At phrenological cabinets, consumers viewed an array of casts, busts and skulls, deliberately arranged. While some cabinets were small, mobile and transported in trunks, most occupied storefronts in towns and cities, merging a museum, an examining room and a bookstore into one. Cabinets mixed the tradition of the private wunderkammer with the emerging model of public museums in the nineteenth century, which was premised on order and expertise. ${ }^{52}$ Phrenological displays combined curiosity and edification, eclectic objects with ordered knowledge. And in that combination came authority. Cabinets contained an array of specimens to illustrate facial and cranial differences and exemplify certain characteristics. Often organised by race or 'nation', and contrasting the criminal and the virtuous, cabinets also presented 'grades' of intelligence from the so-called 'idiots' to the 'giant minds of the world'. While a viewer might take issue with certain points of his or her own reading, it was more difficult to contest a wall of faces. Phrenologists believed such displays could not 'fail to produce conviction in every unbiased mind'. ${ }^{53}$

As users learned about phrenological features, they carried that learning in their daily lives and applied it to living specimens. After three years in the Civil War, William A. Allison wrote to his friend about his belief in phrenology based on his own investigations: 'an observation of the features and formation of the heads of various persons, and a comparison of the peculiar traits of character exhibited by each, has led me to believe that the science has a good foundation'. ${ }^{54}$ Allison engaged in a fairly systematic and comparative survey of phrenological features; his observations convinced him that the science had legs. A.F. Brooks wrote to his cousin, asking after 'Marcia', a potential love interest. 'I was very well pleased with your description of Marcia, but I would like to know the shape and size of her head, for I am a phrenologist.' This self-proclaimed phrenologist wanted Marcia's picture, too, so he could conduct further evaluation. $\mathrm{He}$ described characteristics important to his judgement: 'Light hair and blue eyes indicate a gentle disposition and literary turn of mind[,] a high broad forehead denotes a giant intellect.' He added, 'wide between the ears show the soldier but enough of this' ${ }^{55}$

Some users tested phrenology against their prior assumptions about racial and class differences to create a novel anthropology. Harriet Low Hillard from Massachusetts travelled to Manila and then Macao with her family via the East India Company in 1833-4. In her encounters with non-Westerners, she remarked upon their degrees of civilisation. Confronted with strangers at every port, she used visible and physical signs to generalise about mental abilities. Of the people of Manila bay, she said, 'Their faces

${ }^{51}$ Molina, op. cit. (note 33)

52 Carin Berkowitz and Bernard Lightman, 'Introduction', Science Museums in Transition: Cultures of Display in Nineteenth-Century Britain and America (Pittsburgh, PA: University of Pittsburgh Press, 2017), 1-10.

53 'Article III: Remarks on Phrenological Specimens, Cabinet, Etc.', American Phrenological Journal, 2, 5 (1840), 213.

${ }^{54}$ William A. Allison to Stockton Bates, 18 June 1865, GLC03523.23.42, The Gilder Lehrman Institute of American History.

55 A.F. Brooks to E. Battey, 20 June 1862, Ms. Coll. No. 504. 051, History and Special Collections for the Sciences, UCLA Library Special Collections. 
are not so intelligent. ${ }^{56}$ She met an English phrenologist in Macao, read Johann Gaspar Spurzheim, who had been Gall's assistant, and began to see people through the lens of phrenology. '[I now] look at people's heads very Scientifically,' she wrote. ${ }^{57}$ As she learned about phrenology, she adopted a reference point for testing what she already believed to be Anglo-American superiority; she could now employ phrenology to assess foreign heads and faces as she travelled the world. Phrenology, then, became part of the colonial gaze, and a way to view unknown others.

A surviving copy of George Combe's A System of Phrenology (1838 edition) also shows how anonymous white readers measured phrenological validity against what they already believed to be empirically true about race ${ }^{58}$ Combe's book, part history, part phrenological textbook, described the 'discoveries' made by Gall and Spurzheim through their many observations; it also outlined the nature of each organ, with a particular emphasis on the differences between peoples and 'nations'. In the aforementioned copy, a dubious reader pencilled comments in the footers, indicating a general scepticism toward descriptions of some organs, with words like 'erroneous', 'absurd' and 'great confusion'. ${ }^{59}$ Another reader seemed particularly resistant to Gall's descriptions of Acquisitiveness (the desire to acquire possessions) and Combe's statement that 'The Negroes are also little prone to steal, and the organ is moderately developed in them. ${ }^{60}$ Believing those of African descent were apt to steal, the reader disagreed with Combe, who contradicted their preconceived notions of race and character. Combe's surveys of racial difference, while quite extensive, clearly did not go far enough for some users, who may have also disagreed with his opposition to slavery. ${ }^{61}$ While we know little about this reader, beyond their notes in the book, we can see how some users stood firm with their own version of racism against Combe's science of race. One reader, likely at a later date, pencilled several profile sketches, some of them racially tinged, reifying and duplicating the racialised figures and illustrations in the book. Thus, despite some disagreements with or resistance toward phrenology overall, we can see how readers used it selectively to prop up their own beliefs about racial difference.

For non-white users, much fewer in number, testing phrenology served a very different purpose. While phrenology was used to defend slavery, it was also explored by some abolitionists, a few of them African American, as Cynthia Hamilton has discussed. ${ }^{62}$ For example, the abolitionist William Cooper Nell attended courses given by the Fowlers and reported, '[I] submitted my cranium to their manipulation.' He judged his reading as 'flattering' but still transcribed it in a letter to Wendell Phillips. Fowler said he was

\footnotetext{
${ }^{56}$ Harriet Low Hillard, My Mother's Journal: A Young Lady's Diary of Five Years Spent in Manila, Macao, and the Cape of Good Hope from 1829-34, Katharine Hillard (ed.) (Boston: G.H. Ellis, 1900), 19. In Hillard's diary, see several examples from September 1833, during her visit to Manila.

${ }^{57}$ Ibid., 276-7.

${ }^{58}$ Marginalia undated. This copy can be found in the Alderman Library at University of Virginia (BF870 .C635 1838) and came to my attention via the Book Traces project. See George Combe, A System of Phrenology, 5th American (Boston: Marsh, Capen \& Lyon, 1838), Alderman Library, University of Virginia; Julia Victoria Schrank, 'Book Find: Phrenology, a Seemingly Silly Vintage Science with Dangerous Consequences - Book Traces @ UVA' (n.d.), https://booktraces.library.virginia.edu/book-find-phrenology-a-seemingly-silly-vintage-s cience-with-dangerous-consequences.

59 Ibid., 126, 130, 229.

60 Though partially obstructed, the first word penned in the margin appears to be 'What!!', followed by the denigrating assertion 'Did he ever see a negro!' Ibid., 198.

${ }^{61}$ Hamilton, op. cit. (note 6); Peter McCandless, 'Mesmerism and Phrenology in Antebellum Charleston:

"Enough of the Marvellous",, The Journal of Southern History, 58, 2 (1992), 212.

62 Hamilton, op. cit. (note 6); Britt Rusert, 'The Science of Freedom: Counterarchives of Racial Science on the Antebellum Stage', African American Review, 45, 3 (2012), 291-308.
} 
'a man of integrity... is a practical more than a Theoretical man, is quick of perception, has an excellent memory... is high minded, dignified, aspires to do something worthy of himself, has high hopes....' Importantly, Fowler said, Nell does 'not believe unless he sees the facts in the case'. Nell was possibly testing phrenology for himself but also measuring its effectiveness for arguments against slavery and its potential advantages for his own community. For with phrenology, Nell wrote, he found a way to 'expand a tree of knowledge, from which aspirants for improvement and elevation may pluck the fruit. . , 63

Certainly, there was disagreement among abolitionists about the value of phrenology. Several warned about its dangerous portrayals of racial difference. ${ }^{64}$ Frederick Douglass was among those who directly criticised Samuel George Morton and craniologists, who he said depicted Europeans with 'the highest ideas of beauty, dignity, and intellect', while profiling 'negro imbecility and degradation'. Douglass described how science could produce and disseminate falsehoods: 'science writers, not less than others, write to please, as well as to instruct, and even unconsciously to themselves, (sometimes,) sacrifice what is true to what is popular' ${ }^{65}$ But Douglass too seemed to test the phrenological waters. He called Combe's The Constitution of Man a 'great work', which stood out among the more 'distorted' depictions of African Americans. ${ }^{66}$ One of the most widely read books of the early nineteenth century, The Constitution of Man was as much about natural law and human conduct as phrenology, and was part of a larger nineteenth-century philosophical canon on the mind. ${ }^{67}$ Possibly for that reason, Douglass took interest; he said, it 'relieved my path of many shadows'. And while travelling in Edinburgh, he, William Lloyd Garrison and two others had breakfast with Combe, who, Douglass reported, dominated the conversation and did not '[expect] opposition to his views' ${ }^{68}$ Though judgemental and sceptical of Douglass's overall 'merit', Combe was impressed by his phrenological qualities and wrote to Lucretia Mott: 'Douglas [sic] has an excellent brain. His benevolence and Veneration are both large, \& his conscientiousness [is] full while his intellect is vigorous and practical. ${ }^{69}$ While Combe and Douglass shared opposition to

${ }^{63}$ Dorothy Porter Wesley and Constance Porter Uzelac (eds), William Cooper Nell, Nineteenth-Century African American Abolitionist, Historian, Integrationist: Selected Writings from 1832-74 (Baltimore: Black Classic Press, 2002), 97, 209.

${ }^{64}$ See, for example, 'Equality of Mankind', The Liberator, 22, 16 (16 April 1852), 64. The original letter was published in the American Phrenological Journal and forwarded to The Liberator by 'S.W.', likely Samuel Wells. The letter was authored by an activist offended by its article 'The Five Principal Races of Man', which referenced Caucasian superiority. He threatened to withdraw his support for the Journal, if it continued to 'lend its powerful influence to strengthen colorphobia, and thus to support and perpetuate slavery'. Also, African American abolitionist James McCune Smith used phrenology in order to undermine it. His series of literary portraits, 'Heads of Colored People', reversed the racial typing of African Americans with favourable sketches of their lives and occupations. James McCune Smith, The Works of James McCune Smith: Black Intellectual and Abolitionist (New York: Oxford University Press, 2006), 187-241.

${ }^{65}$ Frederick Douglass, The Claims of the Negro, Ethnologically Considered: An Address before the Literary Societies of Western Reserve College, at Commencement, 12 July, 1854, (Rochester: Lee, Mann \& Co., 1854), 20-1. Douglass also said Morton's 'contempt for negroes, is ever conspicuous'.

66 Ibid., 21.

${ }^{67}$ On reading Combe, see James A. Secord, Visions of Science: Books and Readers at the Dawn of the Victorian Age (Chicago: University of Chicago Press, 2014), chapter 6; Van Wyhe, op. cit. (note 4).

${ }^{68}$ Frederick Douglass, The Life and Times of Frederick Douglass (Hartford, CT: Park Publishing Co, 1882), 299-300.

${ }^{69}$ George Combe to Lucretia Mott, Edinburgh, 7 June 1846, MS 7390, F 16 Letter Book (copies of letters in reply), December 1844-February 1847, George Combe Papers, National Library of Scotland. 
slavery, Douglass mostly remained circumspect about phrenology, for Combe's 'peculiar mental science' did not test well as a benefit for African Americans. ${ }^{70}$

\section{'In the Prosecution of Experiment'}

Phrenologists had long described their science as based on 'observation and experiment', situating themselves among other branches of natural inquiry, such as chemistry and natural philosophy. ${ }^{71}$ In the antebellum United States, practical phrenologists equated cabinets, lecture stages and examining rooms with laboratories, and characterised phrenological encounters of many kinds as 'experiments'. ${ }^{72}$ They framed lectures and debates, public examinations and private readings as not just informative but investigative. And by inviting audiences to take part, they granted consumers some degree of scientific credibility and some room to claim authority. Thanks to phrenologists, consumers were armed and ready to test phrenologists.

To promote the science and discredit critics, phrenologists invited the public to investigate and discover the truth of the science for themselves, and they escorted potential users through a process of 'testing' via hands-on 'experiment'. In April of 1849, the American Phrenological Journal advised readers, 'To be convinced of its truth, nine hundred and ninety-nine men out of every thousand require to SEE it - to be convinced by INDUCTION, founded upon experiment.' The Journal recommended that readers simply observe people and compare their physical manifestations to what they already knew. If you had a neighbour with Firmness in character, they recommended looking to see if his organ of Firmness was 'conspicuous'. But beyond seeing, one really needed to test the validity of phrenology by learning how to measure, in a tactile way, the size of a person's organs. With detailed instructions on moving fingers about the head and locating and gauging the size of organs, the Journal guided readers in how to conduct their own analyses. With this information, 'even disbelievers may test the science', and even 'amateur observers' may be guided 'in the prosecution of experiment'. ${ }^{73}$

Phrenological lectures were also an important site for experiments and knowledge contests. Curious people flocked to learn about the science for themselves, to witness examinations and to hear the debate that followed. For attendees, public forums were edification and entertainment but also participatory, as they observed and reacted to the information presented. Sometimes, lecture halls became sites for sparring matches, which only generated more interest in phrenology.

Phoebe George Bradford, who opened this article, the scrupulous consumer of her own phrenological reading, enjoyed the knowledge contests that played out in her community. A woman of means, Bradford edified herself at sermons, lectures and concerts; she engaged politically, sharing her husband's Whig leanings and associating with the

\footnotetext{
${ }^{70}$ Douglass, op. cit. (note 68), 299-300. Douglass had an 'intense desire' to meet Combe and found 'much satisfaction' in their visit.

${ }^{71}$ George Combe, in particular, framed phrenology as a science of 'experiment and observation'. Combe, $A$ System of Phrenology, 3rd edn (Edinburgh: John Anderson, 1830), 9.

72 Scholars have broadened our notion of the laboratory, to reveal experimentalism and data collection outside academies of science. On institutions as laboratories, see the 2014 History of Science Society meeting panel, 'The Institution as Laboratory: Captive Bodies and the Production of Scientific Knowledge', with papers from Christina Ramos, Courtney Thompson, K.A. Woytonik, Monique Dufour and Andrew Hogan. On gendered users and producers of knowledge outside the academy, see Von Oertzen et al., op. cit. (note 27). On the antebellum stage as site of experimentation, see Rusert, op. cit. (note 61).

73 'Article XXIII: Rules for Finding the Organs', American Phrenological Journal, 11, 4 (1849), 116.
} 
colonisation society (rather than the abolitionists). At a crowded lecture at the Hall of Natural Sciences, she watched as O.S. Fowler both 'amused' and intrigued his audience. He examined several people and then presented samples from his cabinet: 'The busts of Webster and Henry Clay are very fine. The sculls[sic] of murderers, assassins, rogues, warriors, chiefs, idiots and various destructive animals were exhibited and introduced into the Lecture room. ${ }^{74}$ After this public performance, Fowler followed with private examinations, either visits to homes or meetings in his room at the local hotel. In this way, the knowledge exchange could move fluidly from public to private and back and offer more opportunities for the practitioner and the user to analyse and assess each other. And in this community, the debate continued long after Fowler left. A couple of months later, Bradford attended public forums on phrenology. On 28 February 1839, a debate ensued among respected men of the community. She noted:

... went to hear the Docts. essay on Phrenology. I was amused at the discussion, Dr. Naudain defending the hypothesis, Mr. Gilbert admirable on the same side. Benjamin Ferris animated on the subject. Samuel Smith and Henry Gibbons quite warm against Phrenology. Doct. Gibbons lecture was entirely opposed, thinks it will lead to materialism and fatalism. Mr. Ferris promised me to read me his essay on phrenology - I hear it is beautifully written. ${ }^{75}$

Bradford remained engaged and intrigued by all sides of the exchange; this epistemological match, though initiated by a visitor, was now embedded in her community, showing how the contested nature of phrenology only expanded public interest.

Phrenologists created their own knowledge experiments to test the science before public audiences. These were orchestrated demonstrations, deliberately crafted to satisfy dubious onlookers. They often performed their skills by setting up challenging scenarios and overcoming them. For example, some practitioners would offer to conduct phrenological delineations of subjects selected by the audience - persons unknown to them but well known to the community. The community waited to hear if the practitioner's assessment matched what they already knew about the person or foretold his or her future of tragedy or fortune. In the ultimate performance of skill, a practitioner blindfolded himself. Unable to see faces, clothing and manners, and blocked from an audience's reactions to that person, the practitioner was left to use only his hands to decipher character.

Henry B. Gibbons, a roaming phrenologist who lectured all over New York and Massachusetts, had a routine. When he entered a new town, he often assessed the place and its people, whether they were educated or not, cultured or not, and who might benefit from or be drawn into his lecture. While Gibbons strategised about how to motivate audiences, his work was not a scheme, at least in his own eyes. His diary entries repeatedly attest to the veracity and power of phrenology, a gospel he often recited to himself and preached to others. Convincing strangers required making himself familiar and knowable. With a small phrenological cabinet and rolled posters in tow, he introduced himself, posting 'notices' and inviting guests to his temporary residence at the local lodging house. There, he received visitors and conducted analyses before or after public lectures, establishing a rapport with and winning the favour of some townspeople. Knowing some were doubtful, Gibbons conducted examinations upon unknown and unseen subjects. On 3 July 1843, he performed his first demonstration. After lecturing, 'the audience then by my request apointed [sic] a committy [sic] of 3 who selected two candidates for publick [sic] examination. They asked me if I would be blindfolded while examining the second.

${ }^{74}$ Bradford, op. cit. (note 1), 73.

${ }^{75}$ Ibid., 76. 
I proposed to cover his physiaognomy [sic], they firmly agreed. ${ }^{, 76}$ Turning his back to the audience, he let the subjects approach the stage and situate themselves in a chair, hiding their faces. He then would turn around and place his hands on the head of the subject and proceed with his analysis. Later that year, while lecturing in Islip, his audience requested a blindfolded examination, and he was pleased to oblige, for it provided an opportunity to display his abilities. 'They took away the use of my eyes therefore I used no favour or affection,' he boasted, and 'pronounced it the best examination I made in the place. ${ }^{, 77}$ Again and again, he reported in his diary that audiences found his examinations 'strikingly accurate' or 'perfectly correct'.

As Gibbons and others moved from town to town lecturing, they engaged in knowledge contests at every turn, needing to convince new audiences and win over their trust. The knowledge being tested here was both natural and moral, about both science and virtue. ${ }^{78}$ Gibbons relied on client testimonials and letters of introduction to verify that he was both an upstanding person and skilled analyst. In one testimony, a Dr Cady recommended Gibbons and his partner Paul L. Buell based on their science and their character: they "convinced some that were most skeptical on the subject, that the science is not only true, but worthy that attention of all'. As Cady said of Buell and Gibbons, 'as lecturers, as gentlemen, as men of high moral attainments, the above named are recommended to the patronage of the candid public'. ${ }^{79}$ Practitioners also needed to uphold expectations for gendered notions of propriety. For men, this meant demonstrating they were decent, honest and certainly temperate. ${ }^{80}$ As male practitioners' hands explored feminine heads, communities required that they have respectability. In some towns, a group of three to five people, often men of standing or title (such as a physician or minister) but also some ladies, formed a Committee on Examinations or Subscribers Committee, which verified and testified that the practitioner was skilled and upright. They were key players in the knowledge contest, since their judgments could have a ripple effect on the next town. In a signed joint testimony in 1844, one committee documented that Gibbons and Buell had survived their scrutiny: '[we] consider the tests by which we have tried them to be a fair guaranty[sic] of their knowledge of their profession, \& also a proof of the value and usefulness of Phrenological [lectures] to the world' ${ }^{81}$ Committees, thus, were the judges and juries of phrenology, who collectively tried the analyst on behalf of the community.

Consumers initiated ways to test phrenology for themselves while also proving it to others. In 1840 in Taunton, Massachusetts, two citizens, Mr Ziba Babbitt and Mr David Darling, wanted to verify the work of practical phrenologist, Jonathan P. Webster. Both men received character descriptions and charts, of which they were 'satisfied'. Yet they wanted further confirmation, they said, 'not only to satisfy ourselves as to the science, but others of more doubtful minds'. They recounted, 'in consequence of many individuals in this community expressing doubts respecting the truth of the science; we were desirous of

\footnotetext{
${ }^{76}$ Henry B. Gibbons Diary, Volume I, 3 July 1843, Henry B. Gibbons Papers, No. 404, Research Library of the Fenimore Art Museum, Cooperstown, NY.

77 Gibbons Diary, Volume I, 13 October 1843, Henry B. Gibbons Papers, No. 404, Research Library of the Fenimore Art Museum, Cooperstown, NY.

78 Warner, op. cit. (note 9), 15.

79 Marrius Cady Testimony, 30 March 1846, 404/12, Henry B. Gibbons Papers, No. 404, Research Library of the Fenimore Art Museum, Cooperstown, NY.

80 Testimony of Samuel B. Kidder, 10 February 1841, Jonathan P. Webster Papers, Box 3, Oskar Diethelm Library, DeWitt Wallace Institute for the History of Psychiatry, Weill Cornell Medical College.

81 Joint Testimony for Buell and Gibbons, 26 November, 1844, 404/12, Henry B. Gibbons Papers, No. 404, Research Library of the Fenimore Art Museum, Cooperstown, NY.
} 
of [sic] obtaining more thorough conviction of its truth... the test [was] selected by us \& the more doubtful part of the community by which to try him \& his science'.

To satisfy misgivings, Babbitt and Darling asked Webster to re-examine them; they would pay him a second fee, if the two charts agreed. He submitted to their test the very next day. They 'questioned him 'till [they] were fully satisfied; $\&$ in no one instance did he miss'. They and those around them were convinced, they claimed, of the 'irresistable [sic] conviction not only of the truth of the science, but of Mr. Webster's superior skill as a scientific and practical phrenologist' ${ }^{82}$ In this scenario, Babbitt and Darling were initially satisfied with their readings, but their community cast doubt, and they, in turn, questioned their own judgment and gathered more proof.

Testing phrenology also involved games of false identity. ${ }^{83}$ Some doubtful users visited phrenologists in disguise, and often an extraordinary person masqueraded as ordinary. Theodore Weld, the husband of activist and abolitionist Angelina Grimké Weld, explored Grahamism and phrenology as he strayed from traditional spiritual sources. ${ }^{84}$ To test the truth of phrenology, he visited one of the Fowler brothers, not as himself but as an omnibus driver. We do not know the complete nature of his ruse, but he possibly masked the signs of his education and class via dress, speech and gestures. Fowler was 'so struck' that 'an omnibus driver should have such an extraordinary head' that he preserved a copy of his chart as an exceptional case. ${ }^{85}$ Fowler only discovered later that it was Weld. The Welds took this encounter as proof that Fowler would see the real character and talents of a man, despite his appearance.

The British writer and social theorist Harriet Martineau had the opposite experience. At a visit to the phrenological cabinet of James De Ville in London, Martineau and her friends did not share their names or true identities. De Ville, the plaster caster turned phrenologist, was one of the most commercially successful and well-known practical phrenologists of the early nineteenth century. He analysed many famous heads and drew to his cabinet many spectators, who were eager to view his massive collection of specimens, which included skulls and plaster casts of human and non-human crania. ${ }^{86}$ Unaware that he was analysing the head of the accomplished Martineau, De Ville said her life 'must be one of great suffering, because it was a life of constant failure through timidity'. Martineau recounted his analysis: 'I could never accomplish any thing, through my remarkable deficiency in both physical and moral courage.' This caused her entourage to roar with laughter, which gave away her cover. De Ville declared the encounter unfair and asked to visit Martineau again, for a second reading, in her home, but she refused, saying 'an amended judgment could not be worth any thing' ${ }^{87}$

${ }^{82}$ Ziba Babbitt and David Darling to J.P. Webster, 25 September 1840, emphasis original; Ziba Babbitt and David Darling Testimony, 26 September 1840, Box 3, Jonathan P. Webster Papers, Oskar Diethelm Library, DeWitt Wallace Institute for the History of Psychiatry, Weill Cornell Medical College.

${ }^{83}$ For Mark Twain's phrenological experiments, see Alan Gribben, 'Mark Twain, Phrenology and the “Temperaments": A Study of Pseudoscientific Influence', American Quarterly, 24, 1 (1972), 45-68.

${ }^{84}$ Robert H. Abzug, Passionate Liberator: Theodore Dwight Weld and the Dilemma of Reform (New York: Oxford University Press, 1980), 157-60.

85 Angelina Emily Grimké Weld to Jane Smith, 4 February 1837, in Catherine H. Birney, The Grimké Sisters: Sarah and Angelina Grimké, The First American Women Advocates of Abolition and Woman's Rights (Boston: Lee and Shepard, 1885), 163.

86 John van Wyhe, James De Ville (1777-1846), History of Phrenology on the Web, http://www.historyofphren ology.org.uk/deville.html.

${ }^{87}$ Harriet Martineau and Maria Weston Chapman, Harriet Martineau's Autobiography (Boston: J.R. Osgood and Company, 1877), 294-8. 
Although Martineau exposed the failures of such practical phrenologists as De Ville, she had two casts taken of her head and reportedly willed her skull and brain for "phrenological purposes' ${ }^{88}$ She openly admired The Constitution of Man but at times tried to disassociate herself from the science, going so far as to call herself a 'thorough unbeliever' ${ }^{89}$ Martineau engaged more positively with phrenology when it served her, and when it intersected with mesmerism, a practice she favoured and wrote about extensively. ${ }^{90}$ Her encounter with De Ville, and her retelling of it in her autobiography, published in 1877, after her death, allowed her to elevate her own authority in scientific debates, where women had limited voice. Martineau's writings were read in America and her story reflects an important gendered knowledge contestation, in which she was determined to be a winner.

But many phrenological encounters were inconclusive epistemological contests, and they flourished for that very reason. And many phrenologists used uncertainty to garner interest. Jonathan P. Webster's lecture notices did not promise he would reveal the truth but give 'all an opportunity to judge of the truth and practical utility of the science'. ${ }^{91}$ He gave examinations and charts to those who 'wish[ed] to test the truth of Phrenological Science by the application of its principles to their own Heads' (Figure 3). ${ }^{92}$ By urging people to decide for themselves, Webster and other practitioners performed a willingness to share authority - certainly a sales tactic to get curious visitors in the door. Once they were there, he counted on his own showmanship, and the science, to persuade visitors. But it was the opportunity to experiment, to discover truth or uncover fallacies, that drove countless Americans to hear phrenological lectures and have their heads examined.

\section{Conclusion}

As we have seen, phrenological encounters not only served as knowledge trials but as contests over authority. Often, they had no winner, for the exchange itself was most valuable to both the user and the phrenologist; it allowed each to assert their knowledge and judge the other.

This type of knowledge contest depended on a growing consumer health culture in which individuals with means had choices; the ability to discern and select products can be seen in users' responses to phrenological readings. It was also possible due to a middle-class model of self-culture and self-improvement that made phrenology a useful tool, even to those aspiring to be middle class. Accessible cultures of science, based on porous laboratory boundaries, not yet fortified within academies or professional societies, allowed parlours and lecture halls to become laboratories of knowledge.

However, claims that phrenology was somehow 'democratic' do not take into account the unequal power structures that governed the production of knowledge about human difference, particularly in regard to race, gender and mental ability. Phrenology buttressed racial hierarchies that were already firmly in place and repackaged them for audiences

\footnotetext{
88 Ibid., 294.

${ }^{89}$ Harriet Martineau to George Combe, 24 September 1841, 7261, F 58, George Combe Papers, National Library of Scotland. Also cited in Cooter, op. cit. (note 4), 339, note 57.

${ }^{90}$ Cooter, op. cit. (note 4), 121, 196-7, 339, note 57; Harriet Martineau, Letters on Mesmerism, 2nd edn (London: Edward Moxon, 1845); Alison Winter, 'Harriet Martineau and the Reform of the Invalid in Victorian England', The Historical Journal, 38, 3 (1995), 597-616.

91 Jonathan P. Webster Papers, Lecture Notice, unmarked, Box 1, Folder 14, emphasis added. Oskar Diethelm Library, DeWitt Wallace Institute for the History of Psychiatry, Weill Cornell Medical College.

92 J.P. Webster, 'Phrenology Applied', c. 1840, Ephemera Ads 0471. Courtesy of the American Antiquarian Society.
} 


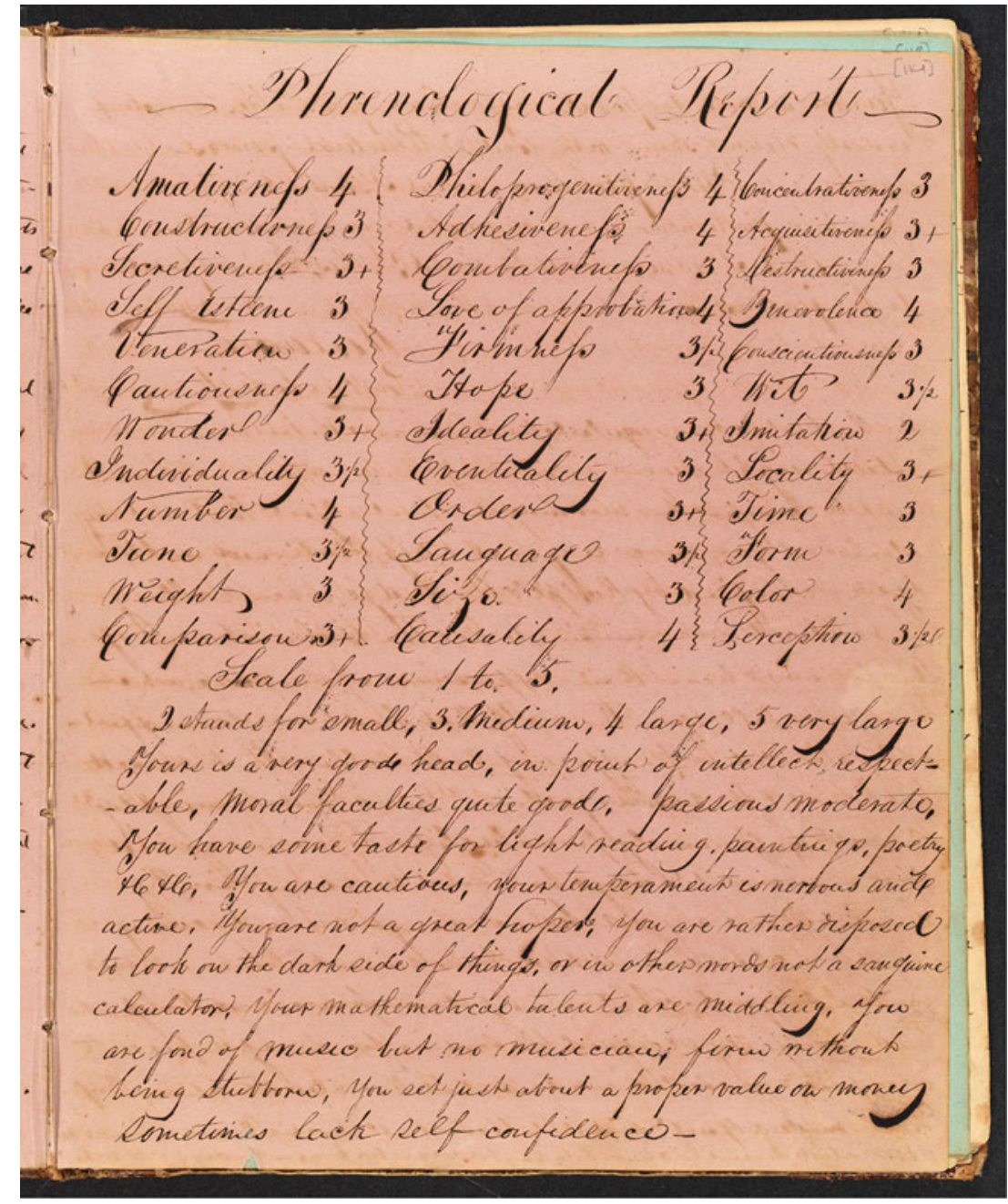

Figure 1: Phrenological Report transcribed in the diary of James Lawrence Dusenbery. Dusenbery Diary and Clipping, 1841-2, \#2561-z, 114-5, Southern Historical Collection. Courtesy of the Louis Round Wilson Special Collections Library, The University of North Carolina at Chapel Hill.

curious about the nature of the mind. Clearly, phrenology systematically categorised people by facial and cranial characteristics and then assigned them particular mental flaws or attributes. It profited from the expanding culture of print in the United States, and it disseminated representations of racial types to a multitude of readers. In the process, phrenology manufactured interest from those eager to affirm their own positions within physical and social hierarchies. As phrenology preached 'know thyself', it instructed audiences to look both inward and outward, to situate themselves as individuals within a vast and increasingly diverse populace. The global was also made local, as skulls and peoples from both near and far became 'national' types for individual comparison, as well as for disassociation and distancing. Many white users, even some with reformist tendencies, measured whether phrenology fit their own views of race and racial notions of self. 


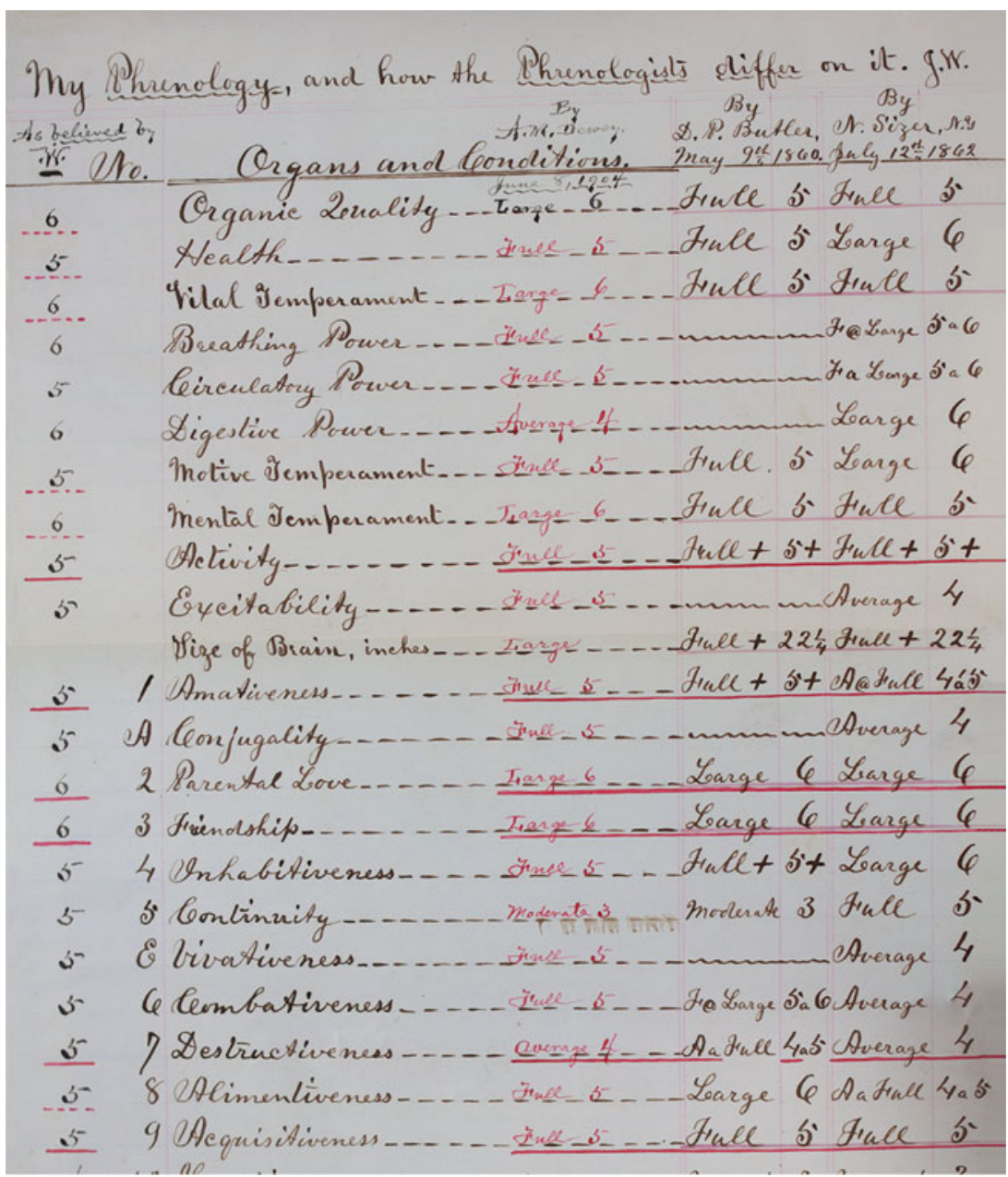

Figure 2: Joseph Wood tested and compared three phrenological readings to his own self-examination. Top segment of 'My Phrenology and How the Phrenologists Differ on It', tipped into O.S. Fowler and L.N. Fowler, New Illustrated Self-Instructor in Phrenology and Physiology (New York: Fowler and Wells, 1852), BF870.F69 1850. Courtesy of the Department of Archives and Special Collections, William H. Hannon Library, Loyola Marymount University.

Phrenology had its true believers and determined critics, but it also became culturally pervasive through sustained exploration, contention and experiment. While phrenologists boasted of their expertise, they equally encouraged others to learn their ways. Clients did not merely engage: they adopted and imitated the rhetoric and practices of science - especially testing and experiment - and used them to evaluate the validity of phrenology. Phrenologists, in person and in print, actively campaigned to disseminate the science, but users also played a significant role, circulating it and diffusing it, even as they called it into question. By going beyond print and prescription, and taking seriously the archival remnants of both the analysts and the analysed, we come to better understand their uneven and reciprocal practices and the contests of authority that drove them. 


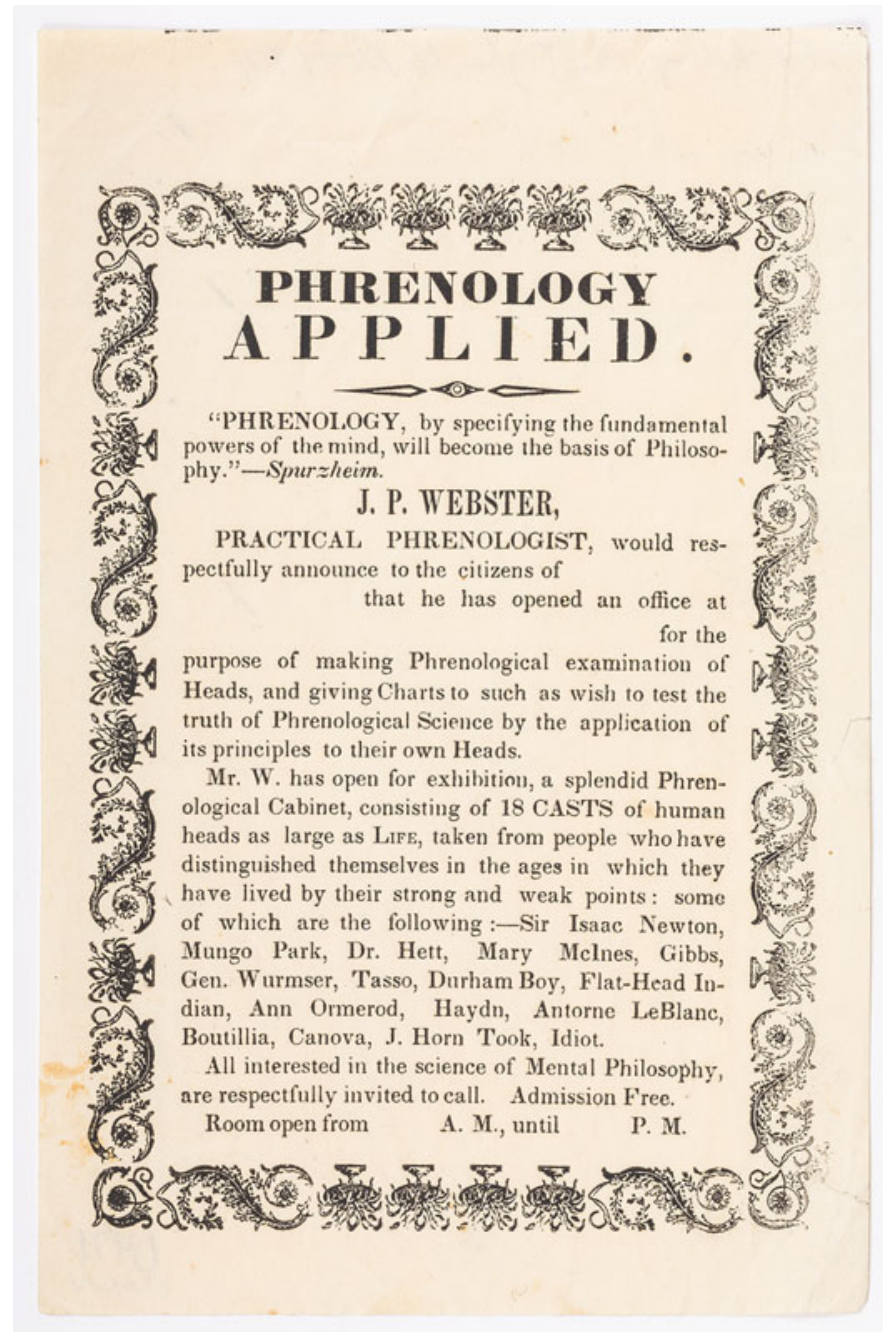

Figure 3: Phrenologist Jonathan P. Webster used printed notices with blanks to customise announcements and advertise his services. He invited local clients to 'test the truth of Phrenological Science'. J.P. Webster, 'Phrenology Applied', c. 1840, Ephemera Ads 0471. Courtesy of the American Antiquarian Society.

Ultimately, phrenology's long history, and the co-constitution of knowledge by phrenologists and clients, set the stage for the dissemination of the brain and mind sciences among an interested public into the late nineteenth and early twentieth centuries. While phrenology per se was unequivocally rejected by the medical establishment, many of its foundations and principles lived on, as brain localisation and forms of measurement became integrated into psychometrics, neurology and psychiatry. ${ }^{93}$ Phrenology also

93 Stephen T. Casper and Delia Gavrus (eds), The History of the Brain and Mind Sciences: Technique, Technology, Therapy (Rochester, NY: University of Rochester Press, 2017); Edwin Clarke and L.S. Jacyna, NineteenthCentury Origins of Neuroscientific Concepts (Berkeley, CA: University of California Press, 1987); Katja Guenther, Localization and Its Discontents: A Genealogy of Psychoanalysis and the Neuro Disciplines (Chicago: University of Chicago Press, 2015); Thompson, op. cit. (note 23). 
remained part of the public imagination, for it established a discourse of the mind premised on self-knowledge and self-evaluation, paving the way for psychotherapeutic regimens and psychoanalysis. ${ }^{94}$ Thus, the epistemological contests carried out by phrenologists and their clients had long-term implications for the negotiation of knowledge and authority by practitioners and patients in medicine and beyond.

94 Sokal, op. cit. (note 2); Sysling, op. cit. (note 3). 